\title{
КАКО СЕ КАЛИЛА ПОСТМОДЕРНА: ДАВИД АЛБАХАРИ КАО УРЕДНИК У ЧАСОПИСУ КЬИЖЕВНА РЕЧ
}

\begin{abstract}
Апстракт: У раду се анализира уредничка активност Давида Албахарија у књижевној периодици, са тежиштем на његовом раду у часопису Кюижевна реч. Оцртавајући контекст у коме се та делатност одвијала, може се реконструисати поетичка и културно-идеолошка слика епохе. Кюижевна реч је као часопис Књижевне омладине Србије излазио у Београду од пролећа 1972. године. Давид Албахари био је члан редакције и уредник за прозу од зиме 1977. до лета 1984. То је време у којем се у српској књижевности довршава доминација стварносне прозе, а на сцену израња нова генерација аутора, која ће нешто касније од критике бити препозната као постмодерна књижевност. Албахари је у том процесу учествовао и као писац и као уредник. У Кюижевној речи, поред прозе младих домаћих аутора, он је објављивао преводе актуелне светске прозне продукције, а пажњу је посвећивао и рокенрол култури.
\end{abstract}

Кључне речи: Давид Албахари, Кюижевна реч, постмодернизам, периодика, кратка прича, рокенрол култура

У овом раду Давид Албахари (р. 1948) биће посматран у донекле неуобичајеном контексту за досадашња проучавања: више као уредник и преводилац него као писац. То ће омогућити да се успоставе везе између та три аспекта његове књижевне делатности, као и да се ближе осмотри његова улога у промовисању нове прозне генерације и новог типа књижевности.

Албахаријев уреднички рад, као саставни део његовог присуства и утицаја у српској и југословенској култури, није једноставно сагледати у целини. Он се шири ван књижевности у ужем смислу у просторе популарне културе и није ограничен само на медиј часописа, јер се прелио у приређивање антологија и уређивање књижевних едиција. Албахари је од 1973. до 1994. био активан у редакцијама неколико часописа, што, биобиблиографски посматрано, обухвата период од објављивања прве књиге до емиграције у Канаду. Почетак његове уредничке делатности везан је за студентски часопис Buguนu. ${ }^{2}$ У Kъижевној речи члан редакције био је од 1977. до 1984, а потом долази рад

1 Стипендиста Аустријске академије наука (DOC-Fellow der OeAW).

2 У периоду 1973-1975. главни уредник „Часописа за културу и уметност студената Београда“ био је Александар Паскаловић. 
у редакцијама часописа Писмо ${ }^{3}$, Мезуза $a^{4}$ и Kulture Istoka ${ }^{5}$. Почетком деведесетих био је уредник за кратку причу у листу Полийика.

Овом приликом пажња ће бити усмерена превасходно на Албахаријев уреднички рад у Кюижевној речи, као једном од најзначајнијих часописа свог времена. Иако је званично припадала тзв. омладинској периодици, Кюижевна реч је, пре свега крајем седамдесетих и почетком осамдесетих, прерасла не само тај првобитно замишљени іенерацијски оквир, него и уско схваћени оквир књижевности, отварајући простор за политичку и идеолошку интервенцију. Како се ради о часопису који још није системски изучаван и обрађен, неопходно је најпре у основним цртама осветлити његову уредничку политику и позицију унутар тадашњег српског и југословенског књижевног поља.

\section{Книжевна реч 1977-1984: кратак преглед}

Књижевна омладина Србије, издавач Књижевне речи, основана је у Београду 1970. и може се посматрати као једна од тековина догађаја из 1968. године. Поред седишта у Београду, локалне подружнице су током наредних година осниване у многим градовима тадашње Социјалистичке Републике Србије. Први број Книжевне речи, као гласила КОС-а, објављен је 1. априла 1972. године. Часопис је на почетку излазио једном месечно, а почев од септембра 1975. у двонедељном ритму, сваког 10. и 25. у месецу. Први главни и одговорни уредник био је Милисав Савић (бр. 1-6, 19-81), који је на тој позицији био током првих пет година излажења листа, са кратким прекидом када су уредници били Срба Игњатовић (бр. 7-17) и Милутин Петровић (бр. 7-18). ${ }^{6}$ Од броја 82/1977 до броја 145/1980 главни уредник је Јовица Аћин, а његов заменик Срба Игњатовић (бр. 101-145).

Давид Албахари постаје члан редакције од бр. 90 (10. 12. 1977), када у уредништво улазе још и Радован Бели Марковић, Драги Бугарчић, Душко Новаковић, Новица Тадић и Гојко Тешић. У јуну 1980. Јовица Аћин прелази у редакцију часописа Delo, а нови уредник Кюижевне речи, од бр. 150 (10.9. 1980), постаје Гојко Тешић. У том периоду уредништво, поред Албахарија, чине Милорад Вучелић, Алек-

3 Први број часописа Писмо излази у пролеће 1985, редакцију су чинили Давид Албахари, Бранко Анђић, Раша Ливада и Дејан Михаиловић.

4 Мезуза: часойис за јеврејску књижевности, гл. ур. Д. Албахари (1993-1994, 1998).

5 Kulture Istoka: časopis za filozofiju, književnost i umetnost Istoka. Нулти број објављен је 1984. (ур. Тоде Чолак); од бр. 3/1985 гл. и одг. уредник био је Душан Пајин; часопис је излазио тромесечно, као издање Дечјих новина из Г. Милановца. Албахари је био члан редакције од „нултог“ до последњег броја (32/1992).

6 Чланови редакције су током тих првих пет година били Гојко Ђого, Мирослав Максимовић, Видосав Стевановић, Радомир Путник, Симон Симоновић, Радослав Братић, Миодраг Перишић, у кратком периоду и Јасмина Лукић. 
сандар Јовановић, Никола Вујчић, Новица Милић и Новица Тадић, нешто касније прикључују се Предраг Марковић (од бр. 198) и Светислав Басара (од бр. 228). Михајло Пантић биће члан редакције током 1983. (од бр. 205 до 224). Од бр. 205 (25. 2. 1983) Давид Албахари има функцију заменика главног уредника. Последњи број Тешићевог уредништва био је троброј 238-240, на осамдесет страна, објављен у лето 1984. Након тога, од бр. 241 (25. 9. 1984), редакцију чине Никола Вујчић (главни уредник), Предраг Марковић (заменик), Милован Марчетић, Светислав Басара, Небојша Васовић и Васа Павковић. ${ }^{7}$

Давид Албахари био је, дакле, члан две уредничке поставке Книжевне речи (под уредништвом Ј. Аћина и Г. Тешића) и његов поетички сензибилитет унеколико је спојница међу њима. Састав Тешићеве редакције окупио је ауторска и критичарска имена која су дефинисала тада актуелну борбу за еманципацију нове, постмодерне генерације писаца. На позадини тог процеса јасно се види двосмерни и узајамни карактер прикупљања симболичког капитала и моћи унутар књижевног поља: недовољно је тврдити да су релевантни уредници и писци учинили часопис релевантним, већ су њихов статус и моћ управо резултат деловања са платформе каква је тада била Кюижевна реч.

\section{Књижевна реч 1977-1984: друштвени, културни и књижевни контекст}

Културно-политички посматрано период који је у фокусу истраживања односи се на године позног југословенског социјализма. Почетак осамдесетих, период који је почео Титовом смрћу, уједно је доба дубоке економске и социјалне кризе у држави. Неприкосновеност социјалистичке идеолошке парадигме се дестабилизује, критика владајућег система јавља се углавном посредно, али са различитих позиција и кроз различите медије. ${ }^{8}$ Постмодерна уметност и књижевност артикулишу се паралелно са другим видовима онога што се сматрало културном и политичком субверзијом. Књижевни часописи су били витални део јавног простора, где су се политика и књижевност вишеструко укрштале. Зато је полемичко-субверзивни аспект Кғижевне речи нарочито значајан и могао би бити предмет посебне анализе. Две најзначајније књижевне и идеолошке полемике тог периода (Данило Киш и Гојко Ђого) прелиле су се и на странице овог часописа. Почетак кризе и друштвене „аутодеструкције“ (Sundhaussen 2007: 379) прекло-

7 На страницама листа штампане су две библиографије, и то у издањима 107 и 108/1978. у два дела је објављена библиографија која покрива бројеве 1-100, док су прилози из наредних сто бројева (101-200) библиографисани у броју 410-411/1993.

8 Један од типичних примера је почетак разбијања табуа о логору Голи оток, и то прво у књижевним текстовима и драми (нпр. Б. Хофман, А. Исаковић, С. Селенић, Д. Ковачевић), а тек потом у публицистици и научној историографији. 
пио се са крајем претходне културно-књижевне епохе, и занимљиво је из данашње перспективе на страницама Кюижевне речи посматрати како тих година одлази низ великана југословенске књижевности, чему је у часопису била посвећена нарочита пажња.

Друштвени контекст у СФРЈ у периоду 1977-1984, статус уметности и књижевности, простори и облици (не)слободе изражавања, могу се ишчитати на примеру односа који је редакција Книжевне речи имала, односно морала имати према председнику државе Јосипу Брозу Титу. Уредништво је наиме балансирало на ивици идеолошки прихватљивог и дозвољене критике. С обзиром на то да је часопис припадао типу омладинске публицистике, не чуди да је неговање Титовог култа као заштитника југословенске омладине било неизоставно и на страницама Книжевне речи. Број часописа који се поклапао са празником Дана младости посвећивао је томе насловну страну и доносио низ апологетских текстова посвећених доживотном председнику, са фотографијама и за то доба типичним двосмерним честиткама: „Срећан ти рођендан, друже Тито“ и „Срећан вам Дан младости, другови и другарице“. У мају 1980. излази специјално издање у целости посвећено преминулом председнику (бр. 146). Након Титове смрти ситуација и друштвена атмосфера се постепено али незаустављиво мењају. У броју од 25. 5. 1981. објављеном на Дан младости након прве годишњице смрти, леву половину насловне странице заузимају Титова фотографија и панегирична песма Бранка Миљковића „Два дана - један дан“, док је на десној штампан говор Чеслава Милоша са доделе Нобелове награде, под насловом „Дистанца је душа лепоте“, што је уредништво несумњиво замислило као прикривену провокацију. Замаскирана алузија и алегорија, типична средства књижевне сатире, нису били реткост на страницама Кюижевне речи и обележили су однос редакције према владајућем политичком систему тих година.

Полемика која је обележила крај седамдесетих у југословенској књижевности - у вези са Кишовом Гробницом за Бориса Давиgовича (1976) - имала је снажан одјек и на страницама Кюижевне речи. Неки од кључних текстова полемике објављени су управо у том часопису (уп. Krivokapić 1980). Став редакције био је одбрана Киша од оптужби за плагијат и истовремено промоција концепта књижевности који је Киш заступао и оличавао. Велики одјек имала је и афера, па потом и јавна полемика око хапшења и затворске казне Гојку Ђогу поводом књиге Вунена времена (1981). Период у коме је Гојко Тешић био уредник Кюижевне речи обележиле су такође сталне полемике редакције са уредништвом студентског часописа Buguци. Два табора међусобно су се оптуживали пре свега за приватизацију часописа и за идеолошки конформизам.

Период у коме је Давид Албахари био члан редакције уједно је био и крај једне епохе, која се из данашње перспективе, упркос огра- 
ничавајућим факторима у друштвено-идеолошком смислу, чини златним добом југословенске уметности и књижевности. Током тих година умиру класици југословенских књижевности 20. века: најпре Иво Андрић (1975), а потом Црњански (1977), Душан Матић (1980), Крлежа (1981), Меша Селимовић (1982), Бранко Ћопић и Марко Ристић (1984). Њихов одлазак био је пропраћен у Кюижевној речи, често на насловној страни, али и низом других текстова и есеја. Занимљиво је да у истом периоду у часопису објављују неки од будућих утицајних политичких актера деведесетих, међу њима (поред Милорада Вучелића који је био члан редакције) Зоран Ђинђић, Војислав Шешељ, Вук Драшковић, Војислав Коштуница. То симболички осликава и заокружује прелаз из једне у другу епоху: exit уметност, enter политика.

\section{Кюижевна реч 1977-1984: уређивачка концепција}

Када се данас сумарно сагледа уредничка концепција Кюижевне речи - од Савићеве до Тешићеве редакције, са Аћиновим периодом као прелазном али прекретничком фазом - може се реконструисати јасна промена поетичког фокуса и интереса уредништва у смеру књижевног модернизма. Трансформација и удаљавање од парадигме тзв. стварносне прозе према актуелним трендовима светске књижевности и теорије, према - условно речено - постмодернизму, била је не само поетичка него и генерацијска и вредносно-сензибилитетска. Узори нове генерације, у оквиру домаће књижевности, били су пре свега Данило Киш и Борислав Пекић. Осим таквог, у поетичко-дијахронијском смислу - модернистичког корака найреg, Кюижевна реч у истом периоду прави и један модернистички корак - уназаg. Захваљујући истраживачком фокусу уредника Тешића и његовог циклуса „Непозната авангарда“, на страницама листа одвија се ново откривање из културног главног тока потиснутог наслеђа српске и југословенске међуратне авангарде. На позадини те реафирмације јасно се огледа и политичка клима тих година, јер се заједно са књижевним делом авангардних аутора, које је претходне четири деценије сматрано неподобним и било скрајнуто, на површину јавности износи и њихово идеолошко залеђе. Ако се оно за тај тренутак и може посматрати као еманципаторско и субверзивно у односу на социјалистички идеолошки монопол у фази опадања, незанемарљиви аспект те реафирмације до краја деценије стапа се са националистичким наративима који су утирали пут распаду земље, а делимично и подупирању каснијег анти-антифашистичког ревизионизма. ${ }^{9}$

\footnotetext{
9 Слично томе, ни поменута промоција постмодерне књижевности осамдесетих није у потоње две деценије остала без свог идеолошког наличја, јер је и у том кругу аутора било оних чија каснија дела и јавни иступи нису остали недотакнути конзервативно-националистички испирисаним ескапизмом, па и отвореном подршком званичној политици национализма и шовинизма.
} 
Укљученост часописа у полемике, које су превазилазиле уске књижевне оквире и прелазиле у домен идеологије и политике, давала је општи тон уређивачкој концепцији, који се огледао и у настојању да се отворено и критички, изван типичног опортунистичког манира, пише о актуелним књигама и битним питањима на књижевној сцени. На страницама Кюижевне речи неретко се могла читати и негативна критика. Најпре у оквиру рубрике назване „Критичко огледало“, а потом „pro \& contra“, објављивана је експлицитно вреднујућа критика, најчешће са негативним ставом о рецензираним насловима, коју су писали Гојко Тешић, Небојша Васовић, Никола Вујчић, Миливој Ненин. Полемички текстови могли су се наћи и изван тих рубрика, по правилу на другој или трећој страници издања, где су објављиване реакције на текстове из претходних бројева и различити прилози дневноактуелног типа.

Уреднички рад Гојка Тешића дао је печат и сатиричкој рубрици „Улица Станислава Винавера“, која је штампана на последњој страници листа. Рубрика је започета у бр. 158 (10. 1. 1981), као вид обележавања 25. годишњице смрти авангардног писца. У том првом издању наведено је да су за „уређење улице“ задужени Миливој Ненин, Сава Дамјанов, Недељко Мамула и Иван Негришорац. Међутим, иако то није експлицитно навођено, из каснијих прилога се види да је и редакција непосредно учествовала у писању и обликовању рубрике. „Улица Станислава Винавера“ прерасла је убрзо у оштру сатиричку бину, посвећену пре свега актуелним књижевним токовима и појавама, али такође окренуту општим друштвеним и политичким питањима. Рубрика је донела вишеделни сатиричко-пародијски лексикон оновремене српске и југословенске књижевне сцене „Who is who“.10

Карактеристични за рад Аћинове и Тешићеве редакције били су темати, често опремљени у облику часописних сепарата, посвећени или посебној теми или опусу неког аутора. Међу њима се могу издвојити „Насиље и књижевност“ (106/1978), „Искушења психоанализе“ (108/1978), темат о сликару Леониду Шејки, који је приредио Бранко Кукић (166/1981), „Пољска књижевност“ (178/1981), „Књижевност трећег света“ (192/1982), као и темати посвећени Џемсу Џојсу (201/1982), Салвадору Далију (225/1984), панк бенду Пан$\kappa р \bar{u} и$ (228/1984) и, у последњем броју Тешићеве редакције, сепарат посвећен Кочи Поповићу (238-240/1984). Иако новинског формата, Кюижевна реч неговала је темате, који као уредничка стратегија имају дугу традицију и посебну културолошку улогу у историји наше периодике (уп. Андоновска 2014: 166-167). ${ }^{11}$

10 На ту серију текстова подсећа рубрика „Булевар звезда“, објављивана у часопису Beton од 2006. Али с обзиром на битно другачији друштвени контекст, Betonova pyбрика је сатирички оштрија и далекосежнија у својој субверзивности главног тока с позиције маргине.

11 Темати су, посебно они у Delu или у часопису Граgаu, били облик личне уреднич- 
Као орїан КОС-а часопис је био фокусиран на српску књижевност, али је, посебно у време Аћина и Тешића као главних уредника, био отворен према другим националним књижевностима и другим књижевним срединама тадашње Југославије. У Кюижевној речи крајем седамдесетих и почетком осамдесетих објављују Тарас Кермаунер, Славој Жижек, Миливој Солар, Зденко Шкреб, Дубравка Угрешић, Владимир Бити, Велимир Висковић, Џевад Карахасан и други. У септембру 1982. објављено је „међународно издање“ часописа, које је у форми антологијског избора донело текстове савремених српских и југословенских аутора у преводу на неки од светских језика. Генерално је Кюижевна реч подстицала преводилачку активност и интеркултурни књижевни трансфер, укупан број објављених преводних текстова није много заостајао за бројем оригиналних текстова домаћих аутора и ауторки. У периоду Албахаријеве уредничке делатности, Борхес је најчешће превођен и тумачен инострани аутор, као и уопште латиноамеричка књижевност - тадашње велико европско литерарно откриће, али незаобилазни су такође преводи савремене англофоне књижевности, затим Сингер, Бекет и други. У посредовању нових токова совјетске литературе посебно је активна Дубравка Угрешић: у јесен 1980. на страницама Кюижевне речи она објављује троделни циклус „Млада совјетска проза“ (152-154/1980) $)^{12}$, а неколико месеци касније и своје преводе Данила Хармса (161/1981).

Књижевна и друштвена теорија, филозофија, пре свега психоанализа и семиотика, заузимали су, поред књижевно-белетристичких текстова и књижевне критике, сразмерно велики део простора на страницама Кюижевне речи, почев од уредничког ангажмана Јовице Аћина. Феминизам и феминистичка теорија, у скромном, али запаженом облику, такође су имали своје место, пре свега захваљујући прилозима Раде Ивековић. Иако је часопис био првенствено књижевни, у њему је објављивана и ликовна, позоришна, филмска критика, извештавано је, на пример, и о радовима Марине Абрамовић. Уметничко је било већ и графичко обликовање листа и прелом текста. Часопис је излазио у великом новинском формату, графички уредници експериментисали су са преломом, ликовном опремом и дизајном, тако да су поједини бројеви битни и као самосвојни дизајнерски артефакти.

ке иницијативе кроз које су увођене културолошке, књижевне и теоријске новине, које понекад ни до данас нису академски стандардизоване. Из тих темата су, такође, настајале хрестоматије и књиге, као у случају анкете о авангарди (уп. Теšić 2002) или темата о Кочи Поповићу, који пада у време кад Тешић приређује две ауторове књиге (уп. Теšić 1985а и 1985b).

12 Исте године Угрешић објављује студију Нова руска йроза: кретиаға у руској совјейској иррози 70-их їодина (Загреб, 1980), а нешто касније и антологију алтернативне руске прозе Пљуска у руиц (Загреб, 1989). 


\section{„Могућности кратке приче“}

Као што је поменуто, Давид Албахари постаје члан редакције Книжевне речи у зиму 1977, убрзо након одслуженог војног рока у JНА, у Бањалуци 1976. године. Претходно је имао уредничко искуство у студентском часопису Вияици. Албахари је тако постао спојница између различитих редакција и генерација, док је у поетичком смислу био ледоломац и предводник не само нове младе генерације него и нове поетичке парадигме у нашој књижевности. Његов уреднички рад у Книжевној речи одвијао се у три домена: први и најважнији је рубрика посвећена краткој причи, други је промоција и увођење рокенрол културе у главни ток књижевности, а трећи се тиче његовог преводилачког рада са енглеског језика, који поред кратке прозе обухвата и поезију и нефикцијске текстове. Као четврти сегмент може се издвојити неколико интервјуа и коментара на различите теме.

Убрзо по уласку у редакцију, у пролеће 1978, Албахари покреће рубрику „Могућности кратке приче“. Први прилог објављен је у броју 99 (25. 4. 1978, стр. 10). Уз кратку причу Мухамеда Шукрија „Жвака“ (прев. с енг. Зора Пузић), штампана је уредничка белешка „Увод у могућности“ у којој Албахари цитира две реченице Владимира Набокова: „О, моја Лолита, само речима могу да се играм“ и „Или ништа неће бити од мог причања, него ће једино остати црна трупла угушених речи“. Те две реченице он означава као метафорично формулисани поетички оквир унутар кога се крећу аутори чија ће проза бити објављивана у рубрици. Албахари се позива такође на појам књижевне „исцрпљености“ Џона Барта, из једног од кључних теоријских есеја америчког постмодернизма, и у том смислу напомиње да ће рубрика сведочити о „НЕмогућностима“ савремене прозе. Он даље говори да ће објављивати ауторе који се баве „побијањем властите форме“, што се може чинити сажимањем (као Борхес) или растезањем (као Пинчон). И једно и друго је, према Албахаријевом мишљењу из уводне белешке, „залудан покушај надвладавања разних обличја ентропије“. Из данашње перспективе, то је занимљив коментар на поетички распон књижевног постмодернизма и на различита тежишта његове рецепције у југословенској култури.

У наредне три године, рубрика, са малим одступањима, излази у месечном ритму и по правилу је штампана напоредо за другом рубриком посвећеном савременој прози, са „Приповедачким видицима“ које је уређивао Драги Бугарчић. Две рубрике биле су у много чему дијаметрално различите: „Могућности кратке приче“ доносиле су искључиво преводе иностраних аутора, модерног књижевног израза и сензибилитета, док су у „Приповедачким видицима“ објављиване приповетке млађих српских и југословенских аутора, блиских поетици стварносне прозе, понекад са тематиком из 
НОБ-а. Постепено, међутим, ту почињу да објављују и аутори нове генерације и модернијег поетичког сензибилитета. Прилози у првој рубрици били су изразито кратки, приче су се понекад састојале од свега неколико реченица, док су у другој штампани вишеструко обимнији прилози.

У рубрици „Могућности кратке приче“ предњачили су аутори који су писали на тзв. великим језицима, пре свега они из англо-америчких књижевности, потом из латиноамеричких и са немачког говорног подручја. За тадашње параметре, нису сасвим били занемарени ни аутори из малих књижевности, што се са друге стране не би могло рећи за статус женског ауторства, јер су готово без изузетка објављивани текстови мушких аутора. ${ }^{13}$ Прилоге су по правилу преводили тада млади преводиоци и преводитељке, од којих су многи касније постали водећа имена у струци. ${ }^{14} \mathrm{He}$ само да је рубрика неретко доносила прве преводе побројаних аутора на српски језик, него су поетички поступци на којима је та проза почивала такође били нови за тадашњу српску и југословенску књижевну сцену. C обзиром на углед и утицај који Кюижевна реч у то време има, таква поетика кратке приче - за коју су кључни немиметичност нарације, метафикционалност, утицај поп културе - снажно утиче на младе ауторе који у том периоду почињу да објављују.

На тај процес Албахари експлицитно указује у уредничкој белешци у броју у којем објављује прилоге тројице младих домаћих аутора: Небојше Јеврића, Бранислава Вељковића и Душана Радивојевића. У том броју (149/1980) рубрика „Могућности кратке приче“ појавила се у облику малог дисперзираног темата. Изразито кратке приче петнаестак аутора - данас би тим текстовима одговарала ознака flash fiction - биле су разасуте на различитим страницама издања. Уз поменуте домаће ауторе, заступљени су, у преводу, и следећи писци: Хулио Кортасар, Дино Буцати, Томазо Ландолфи, Рајнер Кунзе, Олександар Довженко, В. С. Мервин, Васил Холоборотко, Ђерђ Шомљо, Мајкл Вајлдинг, Рајнхард Летау, Расл Едмонд и Антонио Скармета. Том приликом Албахари укратко сумира дотадашњи

13 У прве три године излажења рубрике, објављене су, у хронолошком реду, приче следећих аутора: Ричард Бротиген (101/1978), Зигфрид Ленц (102/1978), Крис Хеменсли (103/1978), Педро Оргамбиде (106/1978), Ари Кинтиља (107/1978), Салвадор Елисондо (112/1978), В. С. Мервин (116/1979), Хулио Кортасар (117/1979), Педро Оргамбиде (121/1979), Аурел Шмит (124/1979), Табан Ло Лијонг (127/1979), Марк Стренд (128/1979), Џон Кејџ (130/1979), Марио Бенедети (133/1979), Ами Карољи (135/1979), Герт Фридрих Јонке (138/1980), Руди Краусман (139/1980), Франц Холер (140/1980), Стефан Лакнер (141/1980), Серђо Сантана (142/1980), Х. Л. Борхес (145/1980), Волф Вондрачек (146/1980), Васиљ Мисик (150/1980), Рајнхард Летау (154/1980), Дино Буцати (155/1980), Варлаам Шаламов (156/1980).

14 На пример, Дубравка Лакић, Живота Филиповић, Бранко Анђић, Мирјана Божин, Звонимир Костић, Ирина Кубик, Марина Миловић, Марта Ковач Кењереш, Жарко Радаковић, Срђан Ђурђов Рашковић, Снежана Минић, Мирјана Огњановић, Јасмина Ливада, Ана Моралић, Божидар Зец и други. 
биланс рубрике и напомиње да је она доносила „преведене приче које се на разне начине противе уобичајеним облицима приповедања“, што се пре свега односи на „сажимање језика и форме“. Та проза, која је остаје изван „код нас уобичајене епске распеваности“, како закључује Албахари, показује „да се и на скученом простору све може изразити: друштвена ангажованост, мит, апсурд, хумор, пародија, сновиђење“ (149/1980, стр. 3).

Од почетка 1981. ритам објављивања рубрике постепено опада, под насловом „Могућности кратке приче“ објављена су свега још два прилога. ${ }^{15}$ Током те године рубрика добија нов, незнатно промењен назив, „Мајстори кратке приче“, и под тим именом ће излазити до почетка 1982, када престаје да постоји. ${ }^{16}$ Међутим, преводи кратких прича аутора сличног поетичког усмерења појављују се на страницама Книжевне речи и након гашења рубрике, а неки од тих текстова наћи ће се касније у Албахаријевим антологијама савремене светске прозе. ${ }^{17}$

Почетком лета 1983, број 213 у целини је био посвећен савременој краткој причи у српској, хрватској и словеначкој књижевности. Темат на укупно 24 странице, који су приредили Давид Албахари, Александар Јовановић, Предраг Марковић и Михајло Пантић, обухватио је како нове текстове тадашње младе генерације југословенских прозаиста, ${ }^{18}$ тако и низ критичко-есејистичких текстова. Био је то закључни кумулативни прилог пред гашење рубрике, али уједно и обележавање почетка пуноправног књижевног живота једног жанра и једне поетике. У уводној белешци стоји следеће:

15 Пародична кратка проза Ђерђа Шпироа „Детектив - story“ (158/1981; прев. с мађарског Клара Потоцки и Младен Срђан Воларевић) и - паралелно уз први прилог у рубрици „Рок култура“ - Албахаријев превод песме/приче „Виђено и невиђено“ Дејвида Бирна, фронтмена групе Talking Heads (165/1981).

16 У оквиру рубрике „Мајстори кратке приче“ објављени су текстови следећих аутора: Карло Емилио Гада (160/1981), Анри Тома (163/1981), Илзе Ајхингер (164/1981), Ђани Родари (166/1981), Марио Бенедети (180/1982), Томазо Ландолфи (183/1982).

17 Иштван Еркењ: „Једноминутне новеле“ (168/1981), Хулио Кортасар: „Усмеравање мачака“ (170/1981), Ален Роб-Грије: „Тајна соба“ (179/1981), Хуан Рулфо: „Живот баш није тако озбиљан у својим работама“ (185/1982), Ив Бонфоа: „Попречна улица“ (190/1982); темат „Књижевност трећег света“ (192/1982): Џума ел Лами „Соб““, Закерија Тамир „Моја последња пустоловина“, Садик Хусеин „Наруквице од злата“; три приче Владимира Казакова „Метаморфоза“, „Шетња“, „Гозба“ (193-194/1982); Славомир Мрожек: „Из дневника маторог ученика“ (195/1982), Данил Хармс „Писмо“ (196/1982), Виктор Јерофејев „Лепа материна“ (197/1982), Бохумил Храбал: „Vademecum обешењаковог ученика“ (200/1982).

18 Српски и хрватски аутори заступљени у темату су: Немања Митровић, Борбен Владовић, Дубравка Угрешић, Зденко Бужек, Никола Искра, Велимир Ћургус Казимир, Владимир Пиштало (који причу „Изабраник“ (стр. 9) потписује именом Милорада Павића и тај поступак поетички образлаже у напомени на стр. 23), Жарко Радаковић, Светислав Басара, Драган М. Кнежевић, Станислав Хабјан, Небојша Стијачић, Мирна Першић, Давор Сламниг, македонски аутор Васе Манчев, Младен Кожул, Миодраг Марковић, Бора Ђоковић, Милоје Радаковић, Миленко Пајић, Љубица Арсић-Панић, Миодраг Вуковић. 
Овим бројем, који је у целости посвећен краткој причи, редакција КЊИЖЕВНЕ РЕЧИ желела је пре свега да забележи појаву бројних младих приповедача у нашој земљи који проблематици и писању кратке приче (и прозе уопште) прилазе са радикално другачијих позиција од генерација које су им претходиле. При том смо имали на уму неколико јасних одредница: промене у структури и језику кратке приче (наспрам доминантних токова који им претходе: фантастика, стварносна проза, традиције реализма и др.), пародијски однос према досадашњим прозним облицима, метапрозни аспект стварања и сл. У исто време покушали смо да утврдимо могуће претходнике овом нараштају приповедача - оне ауторе који су своје прве књиге објавили пре десетак година - и да их критички преиспитамо у новом светлу. Приказивање нових и текућих збивања у појединим приповедачким круговима (новосадски круг, загребачки „хармсовци“, словеначка нова проза) препустили смо тамошњим критичарима, дозволивши им - уосталом, као и свим сарадницима - да проблематику кратких прозних форми обраде и уоче према свом нахођењу. Треба ипак нагласити да овај број ни у ком случају не представља некакав антологијски избор - он је, у најбољем случају, тек подстрек за такав рад - као и то да ови прилози не поричу вредност другим приповедачким опредељењима и поетикама. Другим речима, наша намера није била да наметнемо један јединствени концепт кратке приче, већ да, чак и у оквирима горе наведених одредница, укажемо на плодотворну разноликост неухватљивих кратких форми, као и на чињеницу да се најузбудљивије ствари у свету наше прозе данас догађају управо у равни кратке приче. (213/1983, стр. 2)

Албахари у свом есеју говори о „краткој-краткој причи“ као доминантној форми млађе генерације и описује је као „неухватљиви жанр, негде између песме у прози и прозе у песми“ (стр. 2). Од есејистичких текстова треба издвојити прилог Предрага Марковића „Никад није постојала, сад је нема“ (стр. 3), где се са иронијом говори о „епидемији популарности кратке приче“, пре свега код млађе генерације писаца. Марковић наглашава кључну улогу Давида Албахарија у афирмацији жанра и поетике кратке приче, и то у својствима аутора, преводиоца, уредника и антологичара. Марковић је у закључку скептичан према крајњим дометима кратке приче и говори чак о уметничкој неостварености млађих аутора који у том тренутку фигурирају као главни представници жанра. ${ }^{19} \mathrm{C}$ друге стране, Михајло Пантић у есеју „Увод у кратку причу“ (стр. 4-5) и Добривоје Станојевић у тексту „Кратка прича - жанр или противжанр“ (стр. 8)

19 „Овако, покушај реанимирања кратке приче у коме се тежња ка вишезначности олако претворила у неозначено, само је сведочећи о испразности још једног идејно неосмишљеног подухвата, удобно сместио савремену прозу у опште буновно стање наше јадне лепе књижевности. Уколико вас овај број Кюижевне речи разувери, молим вас пробудите и мене“, закључује Марковић на крају текста. (стр. 3) Ако оставимо по страни Марковићев поетички конзерватизам, његов текст је одличан пример за поменути отворени, полемички дух Кюижевне речи тих година. 
аналитички и у основи афирмативно пишу о форми кратке приче код тадашње младе генерације. Они настоје да се приближе дефиницији жанра и да прегледно опишу његов однос према књижевној традицији. Станојевић анализира прве књиге Немање Митровића, Владимира Пиштала и Драгана Ђоковића, али и Албахаријеве ране збирке, Порояччно време и Обичне ириче. Миливој Сребро, у прилогу „Кратка прича - 'синдром' или дух времена“ (стр. 19), такође пише „нацрт за поетику“ тог жанра.

Аутопоетички есеј, са фокусом на новосадском кругу младих прозаиста, објављује Фрања Петриновић (стр. 14), уз прозу петоро аутора из тог круга (Јованка Николић, Ђорђе Писарев, Сава Дамјанов, Никола Китановић, Слободан Радошевић). Драго Бајт и Денис Пониж пишу есеје о младој словеначкој прози, а од словеначких аутора у темату су заступљени Милан Клеч и Борис Јукић. Бранко Малеш у тексту „Апсурдистички минијатуризам најмлађих хрватских приповиједача“ (стр. 11) пише о помаку поетичке парадигме код тада најмлађе генерације од „борхесовског“ према „хармсовском“ моделу. Темат је заокружен с неколико приказа актуелних књига кратке прозе. ${ }^{20}$ На последњој страни није изостала ни рубрика „Улица Станислава Винавера“, која је тог пута била инспирисана хармсовским апсурдом, примењеним на београдске књижевне прилике.

У преосталом периоду до изласка из редакције Албахари ће још у броју 214-216/1983 уредити темат „Савремена израелска књижевност“ (што долази у време када су дипломатски односи Југославије и Израела били у прекиду), ${ }^{21}$ као и темат под називом „Латиноамеричке књижевности, случајни избор“ $(233 / 1984) .{ }^{22}$

Рубрика „Могућности кратке приче“ приближила је токове савремене светске прозе југословенским читаоцима и (будућим) писцима. Албахаријев уреднички рад одразио се такође на развој његове

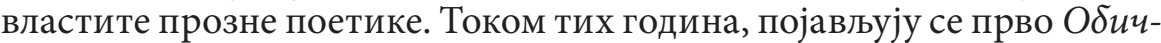
не йриче (1978), а потом и три збирке за које се до данас може тврди-

20 Јасмина Лукић писала је о Дубравки Угрешић, Светлана Слапшак о Велимиру Ћургусу Казимиру, Александар Јовановић о Давору Сламнигу, Сава Дамјанов о Немањи Митровићу, Александар Јерков о Светиславу Басари, Срба Игњатовић о Миленку Пајићу и Михајло Пантић о Миодрагу Вуковићу, а уз то је објављен и интервју Јасмине Лукић са Дубравком Угрешић.

21 Избором од по неколико преведених песма представљени су Јехуда Амихај, Моше Дор, Шломо Винер, Хајим Гури, Далија Равикович, Меир Визелтир, Натан Зах, Т. Карми, Амир Гилбоа, Јааков Бесер, Дан Пагис, док су прозним прилозима заступљени Јааков Бесер, А. Б. Јехошуа, Јицах Орен, Јицах Орпаз, Израел Ефрос. Од тога је Албахари са енглеског превео прозу Јехошуе, Орена и Орпаза, као и поезију Амихаја (с Рашом Ливадом), Визелтира, Заха, Кармија, Бесера и Пагиса (са Зораном Враголовим).

22 Темат је обухватио кратке приче познатих аутора: Х. Л. Борхес, Марио Бенедети, Г. Г. Маркес, Мануел Скорса, Аријел Дорфман и Гиљермо Кабрера Инфанте. Неколико година пре тога латиноамеричка књижевност била је у фокусу темата „Насиље и књижевност“ (прир. Бранко Анђић, бр. 106/1978), за који је Албахари написао уредничку белешку „Загонетка једне теме“ (стр. 1). 


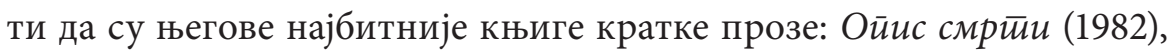

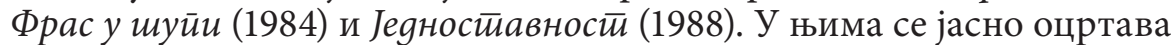
путања поетичког трагања из рубрике „Могућности кратке приче“.

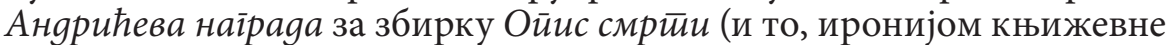

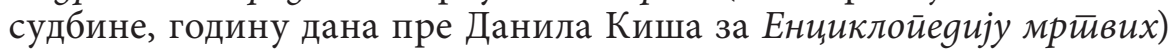
била је не само афирмација и признање Албахарију као писцу него и знак да је поетичко становиште које је заступао и чијој промоцији је одлучујуће допринео уредничким радом у Кюижевној речи, као и другим пројектима о којима ће овде тек бити речи, упливало у главни ток савремене српске и југословенске прозе. Напослетку, искуство година проведених у редакцији и тадашњи београдски књижевни живот постаће касније једна од упоришних тематских тачака Албахаријевог гротескно-сатиричног романа Луgвиі (2007). ${ }^{23}$

\section{Албахари - преводилац}

Као писац, Албахари у Кюижевној речи објављује сразмерно мало, јер је очигледно неписано правило било да чланови редакције не објављују властите белетристичке текстове. Изузетак су били јубиларни бројеви, тако да је Албахаријева проза објављена у броју којим је обележено десет година излажења часописа, ${ }^{24}$ као и у ойрошииајном троброју Тешићеве редакције. ${ }^{25}$ Осим тога, када је у јесен 1983. Албахарију додељена Анgрићева наїраgа, юееіов часопис на насловним странама доноси прво говор Мухарема Первића на додели награде („Привиђења у нашим речима“, 218/1983), а у наредном броју и причу из рукописа „Шта то доказује?“ (219/1983), касније објављену у збирци Фрас у щуйи. Осим тога, Албахаријева проза објављивана је у Кюижевној речи како у периоду пре уласка у редакцију, ${ }^{26}$ тако и након одласка из ње, ${ }^{27}$ а исти је случај и са критичко-есејистичким текстовима о његовим књигама. ${ }^{28}$

23 У приказу романа, Теофил Панчић осврће се управо на статус и позицију тог часописа на оновременој књижевној сцени: „Миље Албахаријевог Луgвиіа београдски је књижевни свет, од 'митских' времена када је оних неколико задимљених квадратних метара шпајз-редакције Кюижевне речи било интелектуално најживље место Београда, па и целе СФРЈ, место на којем су мање-више принудно, али без сумње плодоносно коегзистирали млађани постмодернисти, времешни дисиденти и разни други живописни изданци епохе“ (Pančić 2007).

24 „Гарсоњера“ (186-187/1982)

25 „Моја жена има светле очи“ (238-240/1984)

26 „Приче које један другом причамо“ (11/1973); „Велика побуна у нацистичком логору у Штулну“ (20/1973); „Градски парк“ (30/1974); „Судија Димитријевић се коцка“ (72/1977).

27 „Поетика кратке приче, други део“(265/1985); „Папа“ (287/1986); „Фитиљ“ (300/1987); „Поетика кратке приче, пети део“ (321/1988); „Штросмајер“ (385-386/1991); „Лепота речениц““ (393-394/1992); „Вода“ (400/1992); „Тумачење снова“ (425/1993); „Точак судбине“ (435/1994).

28 Радивоје Микић писао је о првој Албахаријевој књизи Породично време (25/1974). Касније есеје објављују Михајло Пантић („Инстант кратке приче“, 242/1984) и Предраг Марковић („Апатични бунтовник Давид Албахари“, 265/1985). О књизи Јеgносйав- 
Друга је йрича са Албахаријевом преводилачком делатношћу. Прве књижевне преводе, пре свега савремене америчке и британске поезије, Албахари објављује у часописима од почетка седамдесетих, ${ }^{29}$ тада као апсолвент енглеског језика и књижевности на Филолошком факултету у Београду. За време ангажмана у Книжевној речи странице тог часописа пружају фрагментарни али репрезентативни увид у његову преводилачку радионицу, која постепено, поред поезије, почиње да обухвата прозу и есеје. У његовом преводу појављује се, на пример, низ поетичких и аутопоетичких микроесеја аутора попут В. Б. Јејтса („Први принцип“, 102/1978), В. Х. Одна („Поезија као игра знања“, 147/1980) ${ }^{30}$ или И. Б. Сингера („Зашто пишем за децу“, 155/1980) ${ }^{31}$. Први прозни превод у Кюижевној речи, кратку причу Бернарда Маламуда „Писмо“, Албахари објављује неколико месеци пре уласка у редакцију (83/1977). Касније, међу прозама објављеним у рубрици „Могућности кратке приче“, он потписује преводе више прилога. ${ }^{32}$

Од прелаза из седамдесетих у осамдесете Албахари све интензивније преводи прозу. У Радовој едицији „Реч и мисао“ појављују се у његовом преводу књиге Џона Апдајка Разуздани ерос: йриче о Мејйловима (1979), В. С. Најпола У слобоgној gржави (1981) и Сола Белоуа Сребрна чинија (1990). Прелаз из осамдесетих у деведесете доноси врхунац видљивости и утицаја Албахарија као преводиоца на актуелне књижевне токове у Србији и Југославији. Године 1988. он за Народну књигу и БИГЗ приређује Изабрана gела Влаgимира Набокова. Од пет књига обухваћених тим издањем, његов је превод роман Блеgа ватира, као и неколико приповедака унутар тома под насловом Очајаґе - Руска лейойица и gруїе йриче. Потом из штампе излази превод романа Томаса Пинчона Објава броја 49 (1992), прва књига овог аутора на српскохрватском језику. ${ }^{33}$

ности писао је Радивоје Микић (327/1988); о Цинку Добривоје Станојевић (337/1989), Сава Дамјанов (337/1989) и Миљурко Вукадиновић (340/1989); о књизи Пелерина Тихомир Брајовић (414/1993); о Крайкој кюизи Дејан Илић (427/1993) и Марија Кнежевић (427/1993). Интервју са Албахаријем под насловом „Писање је удвајање самоће“ урадио је Милован Марчетић (331-332/1988), а објављен је и српски превод предговора за

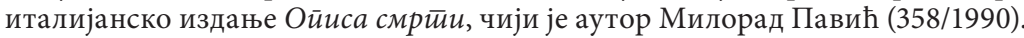

29 То значи практично истовремено са објављивањем првих ауторских текстова. Први прозни текст Албахари наиме објављује у јесен 1969: „Смрт наше мајке“, Млаgости, бр. 680, 23-30. окт. 1969, стр. 28. (уп. Булатовић 1997: 237).

30 Уп. књигу фрагментарне поетске прозе: Вистан Хју Одн Ненайисана йесма (прев. Давид Албахари, Ниш: Градина, 1986).

31 Уп. Исак Башевис Сингер Изабране йриче за gеиу (прир. Давид Албахари; прев. Бојана Албахари и др., Горњи Милановац: Дечје новине, 1988).

32 В. С. Мервин „Улазак“ (116/1979), Марк Стренд „Председникове приче“ (128/1979), Руди Краусман „Мађионичар“ (139/1980), В. С. Мервин „Усамљено дете“, Мајкл Вајлдинг „Гробље 'Смрт прозе““ и Расл Едмонд „Сањарева невеста“ (149/1980).

33 Од каснијих Албахаријевих прозних превода издвајају се приповетке Питера Керија Амерички снови (са Адријаном Марчетић, 1996), романи Телесна йовреgа Маргарет Етвуд (2002) и Савршена ноћ за оgлазак у Кину Дејвида Гилмора (2007), као и низ 
Албахаријеви поетски преводи - објављивани прво у различитим југословенским часописима, а међу њима и у Кюижевној речи, често у сарадњи са Рашом Ливадом или Зораном Враголовом ${ }^{34}$ доживели су неколико монографских издања, која су такође имала одјека у нашој књижевној средини, пре свега, опет, за генерацију младих ауторки и аутора. Међу тим књигама издвајају се две збирке

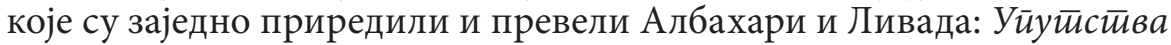
орфичком искушенику Роберта Грејвса (Улазница, Зрењанин, 1975) и књига изабраних песама В. С. Мервина Вашке (Реч и мисао, Рад, Београд, 1979). Осим тога, добар део превода нашао се у различитим, често врло запаженим и поетички утицајним антологијским изборима енглеске, америчке или савремене светске поезије, и то у временском распону од средине седамдесетих (в. Brkić, Pavlović 1975) до средине деведесетих (в. Митровић 1994), па и након тога. Из периода Албахаријеве уредничке делатности у Кюижевној речи незаобилазна је антологија Свейска йоезија gанас, коју је Раша Ливада приредио као посебно издање часописа Граgаи (в. Ливада 1981). У том избору место је нашла поезија многих већ поменутих савремених англофоних песника који су се појављивали на страницама Кюижевне речи. Две године касније, у издању београдске Просветие, појавило се проширено, двотомно издање Ливадине антологије под насловом Модерно свейско йеснишииво.

\section{Албахари - антологичар}

У исто време када Раша Ливада ради на поменутим поетским антологијама Давид Албахари приређује антологије савремене кратке приче. Прва од њих такође се појавила као посебно издање часописа Граgаи, под насловом Савремена светиска йрича (в. Албахари 1979). Аутори заступљени у том избору појављивали су се у рубрици „Могућности кратке приче“, али преводи конкретних текстова били су тада премијерно објављени. ${ }^{35}$ На свега две часописне странице

романа Давида Гросмана: Bugu йog: льубав (2007), Њено тетело зна (2009), До краја земље (2010), Изван времена (2014), Заіррльј (2017) и Кою улази у бар (2017).

34 У првом броју објављен је његов превод стихова Теда Хјуза „Гавранов родослов“, урађен заједно са Ливадом (1/1972). У сарадњи са Враголовом објављује „Три песме“ Марка Стренда (94/1978), према властитом признању у то време једног од својих омиљених песника (Albahari 2010: 38-40). У броју 97/1978 штампан је избор „Савремена енглеска поезија“, који обухвата стихове Филипа Ларкина (прев. Срба Митровић), Теда Хјуза (прев. Д. Албахари и Р. Ливада), Дагласа Дана (прев. Јованка Поповић и Зоран Бундало) и Брајена Петена (прев. Д. Албахари и 3. Враголов).

35 Избор садржи по једну кратку причу следећих аутора: Јехуда Амихај, Џон Апдајк, Џон Барт, Доналд Бартелми, С. Бекет, Х. Л. Борхес, Ричард Бротиген, Гиљермо Инфанте Кабрера, Питер Кери, Х. Кортасар, М. Кундера, Роберт Кувер, Зигфрид Ленц, Табан ло Лијонг, Бернард Маламуд, Г. Г. Маркес, Јан Макјуан, В. С. Мервин, Станислав Мрожек, Грејс Пејли, Харолд Пинтер, Закарија Тамир. (Масно су означени аутори прича које је превео Албахари.) 
предговора под насловом „Артисти и модели“, Албахари уверљиво скицира развојну поетичку линију кратке приче и оцртава генерацијске ауторске таласе, од Бекета и Борхеса, преко америчких постмодерниста, до тада младих Керија и Макјуана. Избор заокружује низ кратких поетичко-биографских портрета заступљених аутора, прегнантно написаних миниесеја са јаким печатом приређивачевих личних читалачких афинитета. ${ }^{36}$ Окосницу избора опет чине англофони и латиноамерички аутори. Америчка проза, по Албахаријевој оцени, има централно место у оквирима тадашње светске књижевности, она не само да највише утиче на остале књижевности света, него је истовремено отворена за утицаје. Приређивач се притом ограђује да нема потпуни увид у актуелну књижевност Далеког истока и Совјетског Савеза.

Након појаве двеју антологија у часопису Граgаи, тадашњи уредник у Просвети, Милорад Павић, нуди приређивачима прилику да објаве проширене изборе. Припремајући нову верзију, Албахари проводи месец дана у Лондону, где ради у Британској библиотеци (уп. Albahari 2010: 46) Резултат је била двотомна антологија Савремена свейска йрича (1982) и данас релевантна панорама кратке прозе друге половине 20. века. За разлику од првобитног избора који је замишљен као нека врста поетичке хрестоматије и ирриручника ${ }^{37}$, Просветино двотомно издање је заокружена, поетички заснована антологија. Англофоно и латиноамеричко језгро из прве верзије проширено је низом аутора и ауторки из других књижевности. ${ }^{38} \mathrm{Pe}$ дослед аутора је генерацијски, а не алфабетски. Такође је и избор текстова модификован у правцу антологијског, будући да због типа публикације није било неопходно да објављени преводи буду изворни.

У предговору, писаном систематичније и амбициозније од уводне белешке уз први избор, Албахари издваја књижевну мими-

36 Уп. нпр. коментар: „Морам признати да ми је Бекет као романописац изузетно досадан“ (Албахари 1979: 114).

37 У предговору стоји да „Савремена светиска йрича представља збир кључних модела или конструкција, просторно и временски разбацаних по Земљиној кугли током последњих десетак година. Ово је значи, приручник, уџбеник, нешто као лексикон приповедачког умећа, зборник форми које приповедач данашњег тренутка треба да упозна како би могао да их се одрекне. Другим речима, ови писци су током последњих десетак година, неки и раније, уобличили и довели до савршенства поједине облике кратке приче“ (Албахари 1979: 5).

38 Антологија је на крају обухватила следећа имена: (том I) Бруно Шулц, Х. Л. Борхес, В. Набоков, В. Гомбрович, Д. Хармс, С. Бекет, Дино Буцати, Жоао Гимараеш Роза, Томазо Ландолфи, Иштван Еркењ, Х. Кортасар, Бохумил Храбал, Џ. Д. Селинџер, Амос Тутуола, Илзе Ајхингер, Ален Роб-Грије, Кобо Абе, Јехуда Амихај, Јозеф Шкворецки, Зигфрид Ленц, В. С. Мервин, Г. Г. Маркес, Карлос Фуентес; (том II) Милан Кундера, Вили Серенсен, Гиљермо Кабрера Инфанте, Џон Барт, Славомир Мрожек, Доналд Бартелми, Томас Бернхард, Зекерија Тамир, Василиј Аксјонов, Роберт Кувер, Мохамед Шукри, Томас Пинчон, Џума ал Лами, Владимир Казаков, Табан ло Лијонг, Петер Хандке, Питер Кери, Виктор Јерофејев, Јан Макјуан. (Масно су означени аутори прича које је превео Албахари.) 
крију као карактеристичну особину прозе обухваћене антологијом и „најмањи заједнички садржатељ“ тог поетичког усмерења (Албахари 1982а: 7). У основи те поетичке позиције је негативни, субверзивни однос према миметичко-реалистичкој прозној парадигми и померање фокуса „са привидно стварне радње на стварање самог дела" (8). За нову кратку прозу, наводи даље Албахари, кључна је пародија. ${ }^{39}$ Тој прози је својствена стилска и жанровска полиморфност („мешање приповедачких поступака, па и самих књижевних родова“), као и интермедијалност („отвореност за утицаје свих медија, од филма до рок-ен-рола“). На крају, пресудно је „сажимање форме“ и „згушњавање језика“ (8). Албахари ни у првој, ни у другој верзији антологије не употребљава експлицитно термин йосиимоgернизам. Уместо њега појављује се ознака метиайроза, што је сигнал о релативно позном етаблирању појма постмодернизам код нас, тек од друге половине осамдесетих. У сваком случају, са или без експлицитног именовања, Албахаријева двотомна антологија била је вршна тачка његовог књижевног актиивизма у увођењу постмодерних форми и садржаја у нашој књижевној средини, врхунац посредовања чији је главни ток годинама пре тога ишао преко страница Книжевне речи и рубрике „Могућности кратке приче“.

\section{„Рок култура“}

Када у предговору антологије из часописа Граgаи говори о тада најмлађој генерацији приповедача, Албахари наглашава да њихова проза припада „времену и култури која носи заштитни знак рокенрола“ (Албахари 1979: 6). Тај културни хоризонт и сензибилитет обележио је и његово одрастање у Београду крајем шездесетих и почетком седамдесетих ${ }^{40}$ што је пресудно за разумевање његових каснијих уметничких и књижевних афинитета. У библиотеци „Печат“, Рад 1980. објављује Албахаријев превод културолошке студије Дика Хебдиџа Пойкулитура: значеюе сииила, свега годину дана након што је та књига о рокенрол култури међу младима у Британији изворно објављена. Стога не чуди да је друга рубрика коју је Албахари покренуо и водио у Кюижевној речи била посвећена управо том, вероватно кључном културном феномену 20. века, и то са нагласком на везама рокенрола и књижевности.

Рубрика под насловом „Рок култура“ први пут се појављује на страницама Книжевне речи у броју 165 (25. 4. 1981, стр. 21). У уводној

39 Из данашње књижевнотеоријске перспективе, након утицајних радова Линде Хачион о постмодерној уметности, где се пародија дефинише као понављање с разликом, начин на који Албахари схвата појам мимикрије у основи је подударан са поступком пародије, тако да тај појам у његовом предговору постаје донекле плеонастичан.

40 Он сам наглашава да је стасавао „у контексту одрастања првих рокенрол генерација у Београду, обележеном рокерском крилатицом 'секс, дроге и рокенрол'“ (Albahari 2010: 48). 
белешци Албахари напомиње да је рокенрол у Југославији за кратко време постао незаобилазна културна чињеница у свакодневном животу младе генерације и наговештава да се као последица тога строге границе између популарне и високе културе све више растачу, да се рокенрол и књижевност све више прожимају. У првом издању рубрика је донела есеј Леслија Фидлера „Будућност поезије. Улога и значај рок музике“ (прев. Јасмина Ливада), док се рубрика „Могућности кратке приче“ симболички претопила у „Рок културу“, па је у њој објављен текст песме „Виђено и невиђено“ бенда Talking Heads, који је Албахари превео и представио као кратку причу.

У наредних годину дана, колико је рубрика активно излазила, унутар ње су се искристалисала два сегмента: у једном су објављивани углавном преводи есеја и одломци из културолошких студија о рокенролу, док је други доносио текстове рокенрол уметника, пре свега са тадашње југословенске музичке сцене. Први сегмент донео је одломак из студије Сајмона Фрита Социолоїија рокан Блејка Морисона о Бииллсмма. Друга тематска линија, која се усталила под насловом „Поетике рок музике“, доносила је аутопоетичке есеје рок музичара или текстове њихових песама. Тако су се на страницама Кюижевне речи појавили Зоран Церар (ТВ Морони), Бора Ђорђевић (Рибльа Чорба), ${ }^{42}$ Бранимир Штулић (Азра), Грегор Томц

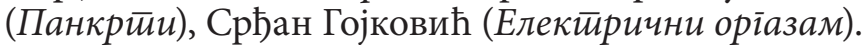

Преко рубрике „Рок култура“ Кюижевна реч је отворила још један канал према актуелним културним токовима и нашла се у дослуху са другим популарним гласилима омладинске периодике, међу њима пре свега са загребачким Poletom и Studentskim listom, који су од краја седамдесетих суделовали у стварању југословенске рокенрол културе.

\section{Албахари - интервјуер и блогер}

Траг у Кюижевној речи Албахари је оставио такође као аутор неколико интервјуа са иностраним ауторима, ${ }^{43}$ али и низом разнородних текстова, бележака, коментара. Тај тип прилога, који су доприносили актуелности часописа и изражавали критичко-полемичку настројеност уредништва, данас би најпре одговарао форми блога. ${ }^{44}$

41 У једном од каснијих бројева Кюижевне речи (186-187/1982) објављен је приказ те студије који потписује Милан Влајчић („Рок и његово окружење“). Влајчић је иначе аутор уводног текста у Албахаријевом преводу студије Дика Хебдиџа Пойкулийра.

42 Бора Ђорђевић и песме Рибле чорбе појављују се касније још два пута у Кюижевној речи (195/1982 и 219/1983), где се контекст све више помера у правцу дневнополитичке провокације.

43 Најчешће је реч о писцима чије је текстове преводио: Марк Стренд (94/1978), Голвеј Кинел (117/1979), Мајкл Вајлдинг (129/1979), Вилијем Саројан (148/1980).

44 Према библиографској класификацији радило се о ставовима (што би значило „по- 
Тема тих Албахаријевих коментара најчешће су биле прилике и неприлике у домаћем издаваштву, као на пример у текстовима „А где је регистар?“ (93/1978) или „Три ствари о којима желим да говорим“ (134/1979). У ту групу се може сврстати и текст објављен у поменутом тематском броју, посвећеном краткој причи, који показује да борба за прозу новог сензибилитета није била само поетичко већ и прагматичко питање издавачке политике, јавног простора за артикулацију, видљивости и доступности тог типа књижевности. У полемички интонираном коментару „Како издати кратку причу“ (213/1983) Албахари критички пише о устаљеној издавачкој перспективи да је „кратка прича роба мање вредности од романа“, односно о несклоности великих издавачких кућа да објављују књиге кратке прозе младих аутора, којима преостаје једино КОС-ова едиција Пеїаз или Прва књиїа Матице српске. Као пример за углед он указује на праксу „издавачких годишњака“ у Великој Британији, који доносе групне изборе текстова младих аутора, што је примерени прелазни ступањ у ауторском сазревању између публикације у часописима и прве књиге. Као блоіер у Кюижевној речи, Албахари објављује и запис у којем представља лондонски часопис Quarto (147/1980).

Међу овом групом прилога издваја се експериментални колажни есеј под насловом „Како сам се нашао између неба и земље“ (78/1977), где Албахари прво скицира (лични) увод у древни кинески филозоф-

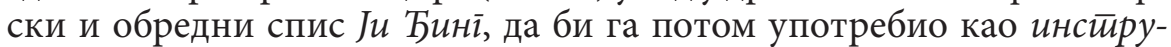
менй за анализу поезије Раше Ливаде. Реч је о спису који је, заједно с другим езотеричним и спиритуалним тековинама Далеког истока, био значајан за развој Албахаријевог интелектуалног сензибилитета. Он је наиме урадио два превода Ји Ђинїа (в. Albahari 1980 и 1982b), од којих ће други постати истински бестселер. Како ће касније сам нагласити, пут до филозофије и мистике Истока водио га је посредним путем, преко рокенрола и хипи покрета, што је уједно линија утицаја која је темељно обележила америчку постмодерну прозу. ${ }^{45}$

Током наредних година Албахари ће, често заједно са колегом из редакције часописа Kulture Istoka, Мирком Гаспаријем, превести низ књига и текстова о зен будизму, хришћанској мистици и јеврејској кабали. ${ }^{46}$ Те различите духовне традиције имаће јасан, често пародиран,

лемике, тезе, спорови, одзиви, одјеци, одговори...“) и коментарима („белешке, кратке вести, записи, коментари, писма редакцији, збивања...”).

45 Уп. „Моје интересовање за источњачку мисао проистекло је из мог интересовања за савремену поп и рок културу. Исток је био један од путоказа битницима, хипицима и свима који су, поготово током шездесетих година прошлог века, хтели да мењају свет. Убрзо ме је привукао зен будизам и наредних година посветио сам му се са искреном аматерском оданошћу“ (Albahari 2010: 40).

46 У ту групу спадају позната монографија Зен Д. Т. Сузукија (1988), затим зен спис Учење о йреношену gуха (1990), есеј Герија Снајдера о екологији и зен будизму у контексту битничког покрета Дух и gивљина (1983), као књига Нормана О’Брауна Тело љубави, езотерични микс психоанализе и хришћанског мистицизма (1989). За часо- 
а понекад само дискретно наговештен одјек у његовој прози. Изразит пример је један од каснијих романа, Пијавице (2005), где је истовремено пародирана и субверзивно употребљена традиција кабале.

\section{Албахари и млаgа срӣска йроза}

У време редакције Гојка Тешића у Кюижевној речи и око ње почиње да се формира језгро нове, младе прозне генерације, која ће ускоро у критици бити означена као млада српска проза, а нешто касније и као генерација постмодерниста. Неке од својих првих текстова на страницама овог часописа тих година објављују Немања Митровић, Владимир Пиштало, Драган Великић, Предраг Марковић, Светислав Басара, Радослав Петковић, као и критичари и теоретичари попут Александра Јеркова или Новице Милића. За ту генерацију Албахаријев уреднички, приређивачки и преводилачки рад је имао поетички форм(ат)ирајућу улогу, и то како кроз рубрике „Могућности кратке прич“ и „Рок култура“, тако и кроз антологије. У едицији Пеїаз, коју је од 1974. издавала Књижевна омладина Србије, прве књиге су објавили многи од поменутих писаца. ${ }^{47}$ У едицији Прва књиїа Матице српске, где је Албахари био у уредништву од 1980. до 1991, такође су дебитовали многи касније етаблирани прозни аутори и ауторке. ${ }^{48}$ То је још један вид Албахаријевог утицаја на српску прозу последњих неколико деценија.

У књизи Искушеюа сажейостии, такође објављеној у Првој књизи Матице српске, Михајло Пантић, оцртавајући „критичку панораму кратких прозних облика у млађој српској књижевности“, на посредан начин сумира поетичке постулате Албахаријеве уредничке и антологичарске делатности. Пантић не само да пледира за статус кратке приче као самосвојног и равноправног књижевног облика, а не „припремног жанра“ за писање романа, него и констатује да је са млаgом срйском йрозом кратка прича заиста постала „пуноправни“

пис Kulture Istoka Албахари, између осталог, преводи текст Гершома Шолема „Гилгул“ (год. 5, 6р. 15, 1988, стр. 33-35).

47 Између осталих, то су прозне књиге: Миодраг Вуковић Круі, собa (1978), Немања Митровић Сан ратиа (1980), Владимир Пиштало Сликовница (1981), Светислав Басара Приче у нестиајану (1982), Сава Дамјанов Истираживаюе савриенстива (1983), Фрања Петриновић и Ђорђе Писарев Мимезис мимезис романа (1983); као и збирке поезије: Никола Вујчић Тајанстивени стирелаи (1980), Васа Павковић Калеияоской (1981), Јелена Ленголд Расйаg ботианике (1982), Божидар Мандић Речи из шуме (1982), Предраг Марковић L'iтип исиеђен (1982).

48 На пример, Љиљана Јокић Амӣула ноћноі̄ леййира (1981), Драган М. Кнежевић Прийойриче (1981), Миомир Удовички Вищеіласје (1982), Драган Великић Поірешан йкрет̄ (1983), Љубица Арсић Прсти у месо (1984), Зоран Пешић Неуравнотежене йриче (1989), Марија Кнежевић Храна за йсе (1989), Ђорђе Јаков Посмайране (1989), Зоран Ћирић Рио Браво (1990), Нина Рабреновић На Среgоземлу (1990), Иванчица Ђерић

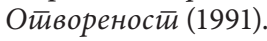


прозни жанр. Као основне карактеристике савремене кратке приче он подвлачи следеће: одступање од епског хоризонта приповедања; сажетост и приближавање поетских и прозних облика; прерушавање (мимикрија) изражајних облика (Pantić 1984: 15-20). ${ }^{49}$ На тим основама је поетички и естетски профил генерације оцртан у низу других критичких и теоријских текстова, као и у књигама Добривоја Станојевића (1985) и Саве Дамјанова (1990), да би као постмодерна формација српске прозе била канонизована у Антологији и студијама Александра Јеркова (1992а и 1992b).

\section{Закључак: књижевни и/или друштвени активизам}

На који начин би се могло говорити о књижевном, односно друштвеном активизму у вези са уредничком концепцијом Кюижевне речи у периоду у којем је члан редакције био Давид Албахари? Шта се може одредити као активистичко у ангажману тог часописа?

Одговор на ово питање несумњиво је одређен специфичностима југословенског социјализма. У периоду о којем је реч (1977-1984) друштвени активизам био је званично промовисан не само као пожељан него готово као обавезујући аспект омладинске периодике, категорије у коју је спадала и Кюижевна реч. И то наравно активизам унутар идеолошког хоризонта социјалистичког самоуправног друштва и његових прокламованих циљева. Али ако би појам књижевног или друштвеног активизма подразумевао компоненту субверзивности према официјелним вредностима и општеприхваћеним друштвеним наративима, онда би се као истински активизам

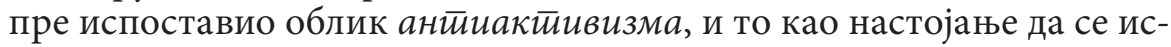
корачи из културне хегемоније наметнутог захтева за активизмом и ангажманом, у смеру простора који би књижевност и јавну реч ослободио идеолошке присиле. У предговору поменутој антологији Савремена светиска иррича Давид Албахари поетику коју промовише одређује управо термином „идеолошки неоптерећена књижевност“ (1982а: 12). У једном од каснијих есеја из књиге Терети он истиче „антиидеолошко одрастање“ своје генерације (коју овде назива постмодернистима) као њену главну одлику (Albahari 2004: 8).

Активизам уредничке концепције Книжевне речи најпре би се могао тражити у промени књижевнопоетичке парадигме коју је часопис у назначеном периоду донео, у увођењу нових идеја и поетичких постулата које је заступао и промовисао. Две главне линије тог импулса биле су: фокус Гојка Тешића на међуратној авангарди и Албахаријев рад на промоцији савремене, постмодерне поетике кратке

49 Кључни аутори генерације за Пантића су у том тренутку: Давид Албахари, Мирјана Павловић, Велимир Ћургус Казимир, Миодраг Вуковић, као и Немања Митровић, Драган Кнежевић, Миленко Пајић и Светислав Басара. 
приче. Такав књижевни активизам на свом наличју је несумњиво значио и - друштвени активизам. Кюижевна реч била је часопис тадашње младе генерације, која - у мери у којој су друштвени оквири то дозвољавали - настоји да активно мења затечено стање у књижевном пољу (што наравно иде подруку са аутопромоцијом). Међутим, илузија да је ияеолошка неойиерећеносй те скупине аутора могла бити и остати неияеолошка, разбијена је потпуно до краја осамдесетих и почетком деведесетих година, када су се ауторске позиције почеле јасно кристализовати у односу на разбуктали национализам као нову централну осу политичког и књижевног поља.

Као активистичка несумњиво се може одредити и Албахаријева преводилачка делатност, као и његов рад на културном посредовању актуелних светских трендова (рокенрол култура). Као књижевни преводилац, Албахари је пре свега радио на поетичком усвајању и промоцији нових ауторских имена и поетичких парадигми, који су од велике важности и за разумевање самог поетичког профила Албахаријеве прозе. Иако у Кюижевној речи не партиципира пре свега својим ауторским прилозима, већ као уредник и инфлуенсер једног новог читалачког укуса, различити аспекти његовог ангажмана у овом часопису заправо су рефлекс и саставни део његове средишње књижевне делатности.

Историзација Книжевне речи сведочи такође о радикалној промени профила и статуса књижевних часописа у постсоцијалистичком контексту: данас нема редакција тог типа нити динамике излажења књижевне периодике и тимског уредничког рада; редакцијски акйивизам је нешто што више не постоји у таквом облику. Осим тога, књижевно поље било је више хијерархијски устројено (што несумњиво има и позитивне и негативне стране), а данашња дигитална разуђеност и непрегледност књижевне сцене тешко се може поредити са тадашњом.

Анализа уредничке делатности Давида Албахарија у Кюижевној речи уједно је поглед у унутрашњост развоја књижевне сцене, а не само Албахарија као писца. Тако је могуће сагледати генезу његовог данашњег ауторског статуса и утицај који је извршио на развој савремене српске књижевности и њен пут у 21. век.

\section{ЛИТЕРАТУРА}

Часописи: Кюижевна реч (1977-1984)

Албахари, Давид (ур.). Савремена свейска иррича. Граgаи, бр. 26-27, јануар-април 1979. 
Albahari, David (prev.). Ji Đing. Knjiga Promene. Beograd: Vuk Karadžić, 1980.

Албахари, Давид (ур.). Савремена свейска ӣрича I-II, Београд: Просвета, 1982a.

Albahari, David (prev.). Ji Đing: knjiga promene (red. Dž. Blofeld), Gornji Milanovac: Dečje novine, $1982 \mathrm{~b}$.

Albahari, David. Teret: eseji, Beograd: Forum pisaca, 2004.

Albahari, David. David Albahari. (Ur. Predrag Marković). Beograd: Stubovi kulture (Pamtivek: knj. 1), 2010.

Андоновска, Биљана. „Часопис као библиографија културе: часопис Дело и проучавање послератне књижевности и културе“. Значај $\delta u$ -

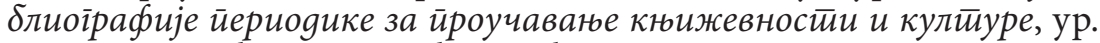
Весна Матовић, Ана Ћосић-Вукић, ИКУМ, Београд, 2014, 155-181.

Brkić, Svetozar i Miodrag Pavlović (ur.). Antologija savremene engleske poezije (prev. David Albahari i dr.), Beograd: Nolit, 1975.

Булатовић, Бранка (1997): „Прилози библиографији Давида Албахарија“. Давид Албахари. Мамаи, (Дела Давида Албахарија, књ. 10), Београд: Народна књига, 1997, 231-260.

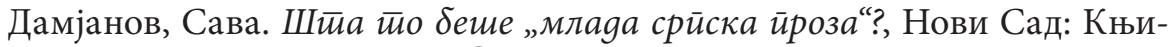
жевна заједница Новог Сада, 1990.

Јерков, Александар (ур.). Анйолоїија срйске йрозе йосймоgерної gоба. Београд: Српска књижевна задруга, 1992а.

Jerkov, Aleksandar. Nova tekstualnost: ogledi o srpskoj prozi postmodernog doba. Podgorica: Oktoih, Nikšić: Unireks, 1992 b.

Krivokapić, Boro (ur.). Treba li spaliti Kiša?, Zagreb, Globus, 1980.

Ливада, Раша (ур.). Свейска йоезија gанас, Градац, бр. 39-40, март-јуни 1981.

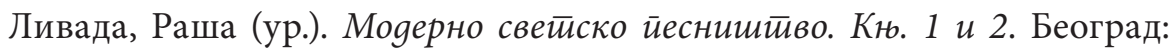
Просвета, 1983.

Митровић, Срба (ур.). Анйолойија америчке ӣоезије 1945-1994 (прев. Давид Албахари и др.), Нови Сад: Светови, 1994.

Pančić, Teofil. „Ruže su crvene...“ (David Albahari: Ludvig, Stubovi kulture, Beograd, 2007). Vreme, br. 876, 18. 10. 2007.

Pantić, Mihajlo. Iskušenja sažetosti: kritička panorama kratkih proznih oblika u mlađoj srpskoj književnosti, Prva knjiga Matice srpske, Novi Sad, 1984.

Станојевић, Добривоје. Форма или не о љубави, Београд: Књижевна омладина Србије (Едиција Пегаз; књ. 83), 1985.

Sundhaussen, Holm. Geschichte Serbiens: 19.-21. Jahrhundert, Wien: Böhlau, 2007.

Tešić, Gojko (ur.). Koča Popović: Nadrealizam \& postnadrealizam, Beograd: Prosveta, 1985a.

Tešić, Gojko (ur.). Koča Popović: Nacrt za jednu fenomenologiju iracionalnog. Hronika lumbaga ili slavenska binda. Beograd: Prosveta, 1985b.

Tešić, Gojko (ur.). Avangarda i tradicija: anketa Književne reči 1980-1982, Beograd: Narodna knjiga (Pojmovnik, knj. 30), 2002. 
Goran Lazičić

Wie die Postmoderne gehärtet wurde.

David Albahari als Redakteur der Zeitschrift Književna reč

Zusammenfassung

Der Aufsatz analysiert die redaktionelle Tätigkeit von David Albahari in Literaturzeitschriften und konzentriert sich dabei auf seine Arbeit in der Zeitschrift Književna reč (Das Literarische Wort), die seit 1972 in Belgrad als Organ der Književna omladina Srbije (Literarische Jugend Serbiens) erschien. David Albahari war vom Winter 1977 bis zum Sommer 1984 Mitglied der Redaktion. Dies ist eine Zeit, in der die Dominanz der sog. Wirklichkeitsprosa in der serbischen Literatur zu Ende geht und eine neue Generation von Autoren in Erscheinung tritt, deren Literatur später als postmodern bezeichnet werden sollte. Albahari war sowohl als Schriftsteller als auch als Redakteur an dem Prozess beteiligt. Im Literarischen Wort veröffentlichte er neben der Prosa junger heimischer Autoren auch Übersetzungen zeitgenössischer internationaler Prosa und widmete sich zudem der Rock'n'RollKultur. Der Artikel skizziert den Kontext, in dem er dieser Tätigkeit nachging, und versucht, das poetische und kulturideologische Bild der Epoche zu rekonstruieren.

Schlüsselwörter: David Albahari, Književna reč, Postmodernismus, Kurzgeschichte, Rock'n'Roll-Kultur 